Original Research

\title{
The Protective Role of Ectomyccorhizas in Relation to Pinus sylvestris L. Growing in Areas Contaminated with Heavy Metals
}

\author{
Katarzyna Maria Bandurska*, Agnieszka Katarzyna Berdowska, Piotr Pawel Krupa \\ Faculty of Science and Technology Jan Dlugosz University in Czestochowa, Poland
}

Received: 23 August 2018

Accepted: 25 July 2019

\begin{abstract}
The study demonstrated protection role of ectomycorrhizae for pine (Pinus sylvestris L) growing on areas with high contamination of heavy metals such as cadmium $(\mathrm{Cd})$ and lead $(\mathrm{Pb})$. Investigation of mycorrhizae growth dynamics, dependence of the accumulation of heavy metals in mycorrhiza and individual components of pine biomass growing in areas with varying degrees of exposure to heavy metal emissions were conducted.

During field studies strong accumulation of $\mathrm{Cd}$ and $\mathrm{Pb}$ in mycorrizosphere was observed. Comparison of metal elements content in pine biomass showed the retention of metals in mycorrhizae. Confirmation of field observations was done next in the laboratory. In mycorrhizal tests sterile pine seedlings showed comparable amount of $\mathrm{Cd}$ and $\mathrm{Pb}$ accumulation in underground and aerial parts. Mycorrhizal seedlings accumulated these metals primarily in the roots, thus protecting the aerial parts of seedlings from contamination.

It is shown the positive role of ectomycorrhizae as an active filter that protects plants from heavy metals contamination.
\end{abstract}

Keywords: ectomyccorhizas, heavy metals, Pinus sylvestris, soil contamination

\section{Introduction}

Under the influence of anthropogenic factors, the natural environment is subjected to far-reaching changes that threaten the existence of life. Advanced industry with its "dirty" and energy-intensive technologies continually contributes to the pollution of

*e-mail: kbandurska@hotmail.com the environment. Huge amounts of zinc, lead, cadmium, copper and iron emitted with dust interact in various ways on soil and plants. As a result of an excessive concentration of heavy metals, a natural biological system is distorted and usually leads to a malfunction of living trees, forest floor vegetation, soil microflora and changes in the activity of many soil enzymes [1-3].

Plants adapting to polluted industrial environments have developed a number of mechanisms designed to protect them from contamination. The deposition of impurities in the cells and precipitation of 
insoluble metal compounds through root secretion is a well known phenomenon. More and more attention has been paid to microorganisms that may play an important role in soil remediation and protection of plants from contamination. Common coexistence of higher plants with mushrooms is inclined to believe that mycorrhiza is one of the protective mechanisms in plants [4-8]. Numerous literature reports demonstrate that mycorrhiza increases the effectiveness of absorption of water and nutrient elements (such as N, P, K, Ca) [9-11]. Questions we considered are: 1) whether heavy metals such as zinc, cadmium and lead are effectively taken from the soil and transmitted to plants or 2) do fungi perhaps restrict the flow of these elements? Preliminary field observations have indicated that in extreme ecological conditions, for example, in the immediate vicinity of the ferrous metal smelter, only trees with highly developed mycorrhizal systems survived. This suggests that the existence of the mycoremedation of soils is contaminated with heavy metals.

The aim of our study was to confirm the mycoremediation of soils and to examine whether ectomycorrhizae of selected tree species (Pinus sylvestris L.) inhibit the translocation of cadmium and lead to the cells of the host plant, or facilitate the flow of these elements from soil to plants.

\section{Materials and Methods}

\section{Collection of Materials}

The materials for the study were: soil, roots, stems and needles of 1-year-old pine. Samples were collected following the recommendations of Namieśnik et al. [12] and Wyciślik [13].

In the case of mycorrhizae the phenomenon of the periodic resumption of their growth was used [14]. At this time, living mycorrhiza are strongly thickened and covered by mantle hyphae colored from almost white to yellow, making it possible to easily distinguish between mycorrhizal and non- mycorrhizal roots, and dead from live mycorrhiza. This phenomenon can be observed twice a year: in the spring (in late April and early May), and in the autumn (October-November). These periods were determined as the time of harvesting. The first is defined as "spring" and the second as "autumn".

\section{Preparation of Materials for Analysis}

The material obtained from the area was cleaned thoroughly in the laboratory. The roots were rinsed in running water, and then divided by mycorrhizal and nonmycorrhizal parts. In addition, more accurate cleaning of stems was done under the binocular using needles and distilled water. The plant material was mineralized by wet method in a speed wave microwave device (Speedway-Berghof) introducing metals into solution of $2 \mathrm{~N} \mathrm{HNO}_{3}$ [15]. The soil samples
(10 grams) from all three areas were collected from surfaces $(1-10 \mathrm{~cm})$, then shaken for 1 hour in $100 \mathrm{ml}$ of $0.1 \mathrm{~N} \mathrm{HCl}$. After that, the solution was filtered through a thick paper filter and studied by voltammetry. Soil $\mathrm{pH}$ was determined potentiometrically in double-distilled water.

\section{Chemical Analysis of the Material}

For markings of metals in field and control samples, the method of anodic stripping voltammetry (ASV) was applied. During analyses, a coulometric analyzer microtraces EcaFlow 150 GLP (Istran) was used in accordance with the recommendations [16].

\section{Isolation of Mycorrhizal Fungus}

Mycorrhizal fungi were isolated from mycorrhizae pines growing on experimental plots, according to the methodology described by Krupa [14]. After the strains' selection, for further experimental work, strain "A1" from Miasteczko Śląskie was used. It is characterized by rapid growth, high mycorrhizal activity and tolerance for heavy metal soil contamination.

\section{Identification of Strain A1}

Fruiting bodies of fungi of all species were harvested from the research plots. After transportation to the laboratory they were inoculated on agar medium, and then clean lines were obtained. Grown mycelia were compared to a selected mycelium of "A1" strain. Morphological diagnostics were verified by molecular analysis of fungal rybosomal DNA (rDNA) by polymerase chain reaction (PCR) in combination with restriction fragment length polymorphisms analysis (RLFP). Experiments were carried out according to the procedure described by Krupa and Kozdrój [17].

\section{Culture of Control Seedlings}

Sterilized perlite was used as a medium for control seedlings culture. The pine seeds were stratified at $+2^{\circ} \mathrm{C}$ for two weeks before sowing. Vases were divided into two series: a mycorrhizal inoculated A1 mycelium (aqueous suspension of the mycelia obtained from the culture agar $\left(100 \mathrm{~cm}^{3} / 1 \mathrm{dm}^{3}\right.$ substrate) and nonmycorrhizal). Vases were watered once a week with water with the addition of lead acetate $(50 \mathrm{mg} / \mathrm{g})$ and cadmium chloride $(30 \mathrm{mg} / \mathrm{g}) ; \mathrm{pH}$ of the solutions was even out to 5.5 .

Observations were made over a period of three months. Seedlings were grown with lighting for 6 hours per day (mercury light bulbs and fluorescent "Flora"type tubes). After this period, the seedlings were carefully pulled out of the perlite and morphologicaly analyzed. The content of heavy metals was then tested in the underground and aboveground parts of seedlings from the first and second series. 


\section{Selection and Characteristics of Surface}

\author{
The Choice of Experimental Plots
}

The choice of research areas was preceded by field reconnaissance. The samples of pine trees originating from different regions of Upper Silesia, taken from similar habitat types and heaps, were subjected to spectrophotometric analysis on heavy metals content.

Based on the analysis presented in Table 1, it was decided to conduct further studies on three areas with various degrees of heavy metal contamination:

1. Piekary Śląskie area research was located on the metallurgical heap made by the White Eagle Company; this city is characterized by one of the highest rates of air pollution in Silesia.

2. Miasteczko Śląskie area research located in the vicinity of the smelter of zinc and lead, in the treelined artificial birch, pine and red oak in industrial desert created around the smelter.

3. Kokotek (forestry Lubliniec) area research in Częstochowa-Lubliniec forest complex, which forms a protective belt belonging to GOP, situated beyond the impact of bigger industrial emissions.

\section{Soil Conditions}

Silesian town and Kokotek surfaces are characterized by podzolic soil ranging from 3.5 up to $4.0 \mathrm{pH}$ in the humus and from 4.5 up to $6.0 \mathrm{pH}$ in the bedrock. As a result of significant amounts of dust containing metal oxides, Miasteczko Śląskie has observed gradual alkalization of the soil along with an unfavorable ratio of carbon to nitrogen (C:N $=25: 1)$.

The heap in Piekary Ślaskie is built from the ironwork waste material (granulation 1,5-2 $\mathrm{mm}$ ) predominantly composed of dolomite crumb mixture, sinter slag and burned coke. The period of formation is 1926-1960. Soil pH is 6.5-8.0.

Based on the analysis of phytosociological pictures, we found that the research surfaces of Miasteczko Śląskie and Kokotek main trees community is Leucobryo-Pinetum from team Dicrano-Pinion libb. 1933. In Piekary Śląskie, however, in place of taken samples was a distinguished community of uncertain syntaxonomical affiliation: Betula pendula assemblage of Pinus sylvestris and Populus tremula. It is one of the most common communities in mining and metallurgical heaps [18].

\section{Results and Discussion}

Heavy metals are taken by the plants from the soil through the root system similarly as the macronutrients and micronutrients. Deficiencies of micronutrients in the soil often result in the accumulation of heavy metals in plants. Stress caused by an overload of heavy metals causes disturbances in the metabolism of plants and the assimilation of macro-and micronutrients. Microorganism activity in the ryzosphere plays a major role in growth of the plant [19].

Symbioses between beneficial soil microorganisms and plants are known to support plant growth and help plants deal with various environmental stresses. During mycorrhiza establishment, modulation of plant defense responses occurs (such as an effective activation of the plant locally and systemically through immune responses) [20].

In nature, heavy metals occur in small concentrations in rocks, soil and water [21]. It is widely recognized that increased content of heavy metals in soils is an indicator of anthropopressure in the area [22-23]. These allegations are confirmed by the results of this study presented in tables.

The obtained results of measuring the content of heavy metals in soils (Table 1) were generally in agreement with the values presented by other authors [22-23]. The level of metals in the soils of the Miasteczko Śląskie and Piekary Śląskie exceeded a dozen or even several dozen percent of the standards set in the Regulation of the Minister of the Environment [24].

Interesting, however, are results presented in Table 1 regarding differences between the total metal content to be tested in the soil and leachable water. This difference may be one of the reasons why living plants can survive in areas where the general contamination of the ground reaches up to several thousand $\mu \mathrm{g} / \mathrm{g}$ of dry mass. In the literature, mostly general content of heavy metals is reported. Although the total content of heavy metals is a potential threat, heavy metals are mostly immobilized, and thus harmless at the moment [25]. The plants get essentially the soluble fraction which, for example in Piekary Ślaskie is comparable to the amount in Miasteczko Ślaskie even though the total content of $\mathrm{Pb}$ in the Piekary Ślaskie heap was about 20 times greater. Soil $\mathrm{pH}$ plays a major role in the availability of minerals - including heavy metals. At the heap, alkalization of soil $\mathrm{pH}$ was between 7 and 8 . This explains the low content of water-soluble fractions of studied heavy

Table 1. Mean content of extractable and total cadmium and lead in soils of experimental areas ( $\mu \mathrm{g} / \mathrm{g}$ dry soil); mean $\pm \mathrm{SD}$.

\begin{tabular}{|c|c|c|c|c|}
\hline \multirow{2}{*}{ Spot } & \multicolumn{2}{|c|}{ Content of Cd } & \multicolumn{2}{c|}{ Content of Pb } \\
\cline { 2 - 5 } & Total & Water extractable & Total & Water extractable \\
\hline Piekary Śl. /heap/ & $101.3 \pm 7.7$ & $1.4 \pm 0.9$ & $3371.4 \pm 194.9$ & $7.8 \pm 0.8$ \\
\hline Miasteczko Śl. & $19.6 \pm 1.7$ & $0.6 \pm 0.2$ & $209.2 \pm 32.6$ & $4.7 \pm 1.8$ \\
\hline Kokotek & $0.9 \pm 0.1$ & $0.1 \pm 0.06$ & $6.5 \pm 0.6$ & $0.8 \pm 0.4$ \\
\hline
\end{tabular}


metals. Causes of inhibition of translocation of heavy metals may be many, for example loam fractions, and humus and structural substances of soil. A major role is attributed to the biotic factors, which have a notable impact on soil sorption. The study soil taken from the root rhizosphere was influenced by root, bacterial and fungal exudates causing precipitation of cations. Recent reports suggest that mycorrhizae can play a leading role in the mentioned process [26-27].

Tables 2-4 illustrate the contents of cadmium and lead in the individual components of tree biomass. The role of mycorrhizae is often not considered in literature, although in view of the presented results it has a strong influence on the level of $\mathrm{Pb}$ and $\mathrm{Cd}$ in plants. Studied heavy metals localized primarily in roots mycorhizosphere. Even in a relatively low contamination of soil (Kokotek), accumulation of heavy metals in the root zone was considerable. For example, the level of cadmium and lead reached up to $12.6 \mu \mathrm{g} / \mathrm{g}$ of dry mass and $62.5 \mu \mathrm{g} / \mathrm{g}$ of dry mass respectively. Zones of non-mycorrhizal roots and thick roots of firstorder contained less of the metals than the stems or needles (Tables 2 and 3).

Table 5 shows the results of mycorrhizal observation. The highest accumulation of mycorrhizae was observed in Piekary Ślaskie despite the heavy load of the area with heavy metals. These observations are in agreement with already published results, which leads to the conclusion that plants build strong mycoorhizas as soil conditions worsen [14, 28-30]. Although by „difficult conditions" the authors understand poverty of minerals, it seems justified to extend the definition to soils contaminated by industrial emissions. The need of extended mycorrhizal system formation is due to the "help" of plants in the competition for biogenic elements, particularly those that exist at a minimum level in the environment. Increased collection of minerals described by many authors was also reflected in the results of the presented work [11, 31-32]. It should be noted, however, that in extreme living conditions the majority of pine mycorrhizae were dead at the end of the vegetative cycle. This suggests their low life vitality. Undeniable is also the reduction in number of fungi species typical for ectomycorrhizas such as Basidiomycota in favour of Ascomycetes, which is also noted by other authors [14, 33-34].

The presented results (Tables 2 and 3) also show increased collection of $\mathrm{Cd}$ and $\mathrm{Pb}$. However, although these heavy metals have been extensively taken from soils and heaps, further transport of these metals to the pine biomass was strongly inhibited by mycorrhizae.

Reports indicating a restriction on the movement of certain metal ions by mycorrhizae were also presented in the literature [14, 35-36].

Table 2. Content of cadmium and lead in pine roots growing in selected areas ( $\mu \mathrm{g} / \mathrm{g}$ dry mass); mean $\pm \mathrm{SD}$.

\begin{tabular}{|c|c|c|c|c|}
\hline \multirow{2}{*}{ Spot } & \multicolumn{2}{|c|}{ Content of Cd } & \multicolumn{2}{c|}{ Content of Pb } \\
\cline { 2 - 5 } & $\mathrm{M}$ & $\mathrm{BM}$ & $\mathrm{M}$ & $\mathrm{BM}$ \\
\hline Piekary Śl. /heap/ & $82.1 \pm 5.5$ & $9.6 \pm 0.6$ & $2277.1 \pm 75.4$ & $132.2 \pm 4.4$ \\
\hline Miasteczko Śl. & $39.3 \pm 3.6$ & $18.7 \pm 2.2$ & $2146.8 \pm 310.2$ & $134.3 \pm 11.4$ \\
\hline Kokotek & $10.6 \pm 1.8$ & $0.1 \pm 0.05$ & $59.3 \pm 3.7$ & $8.8 \pm 0.3$ \\
\hline
\end{tabular}

$\mathrm{M}$ - in mycorrhizal roots; BM - in non-mycorrhizal roots

Table 3. Contents of cadmium and lead in pine annual shoots ( $\mu \mathrm{g} / \mathrm{g}$ dry mass); mean $\pm \mathrm{SD}$.

\begin{tabular}{|c|c|c|c|c|c|c|}
\hline \multirow{2}{*}{$\begin{array}{c}\text { Vegetation } \\
\text { season }\end{array}$} & \multicolumn{4}{|c|}{ Spot } \\
\cline { 2 - 7 } & \multicolumn{2}{|c|}{ Piekary Śl. /heap/ } & \multicolumn{2}{c|}{ Miasteczko Śl. } & \multicolumn{3}{c|}{ Kokotek } \\
\cline { 2 - 7 } & $\mathrm{Cd}$ & $\mathrm{Pb}$ & $\mathrm{Cd}$ & $\mathrm{Pb}$ & $\mathrm{Cd}$ & $\mathrm{Pb}$ \\
\hline Spring & $17.0 \pm 1.7$ & $327.3 \pm 5.9$ & $11.5 \pm 1.2$ & $223.6 \pm 30.5$ & $1.6 \pm 0.5$ & $12.5 \pm 0.7$ \\
\hline Autumn & $25.6 \pm 2.9$ & $569.2 \pm 56.8$ & $22.1 \pm 3.5$ & $319.9 \pm 24.1$ & $3.3 \pm 0.6$ & $29.7 \pm 4.5$ \\
\hline
\end{tabular}

Table 4. Contents of cadmium and lead in pine annual needles ( $\mu \mathrm{g} / \mathrm{g}$ dry mass); mean $\pm \mathrm{SD}$.

\begin{tabular}{|c|c|c|c|c|c|c|}
\hline \multirow{2}{*}{$\begin{array}{c}\text { Vegetation } \\
\text { season }\end{array}$} & \multicolumn{4}{|c|}{ Spot } \\
\cline { 2 - 7 } & \multicolumn{2}{|c|}{ Piekary Śl. /heap/ } & \multicolumn{2}{|c|}{ Miasteczko Śl. } & \multicolumn{3}{c|}{ Kokotek } \\
\cline { 2 - 7 } & $\mathrm{Cd}$ & $\mathrm{Pb}$ & $\mathrm{Cd}$ & $\mathrm{Pb}$ & $\mathrm{Cd}$ \\
\hline Spring & $7.5 \pm 0.6$ & $61.6 \pm 7.8$ & $8.9 \pm 0.7$ & $202.4 \pm 16.2$ & $0.7 \pm 0.2$ & $8.3 \pm 0.5$ \\
\hline Autumn & $17.7 \pm 2.2$ & $161.5 \pm 6.2$ & $15.51 \pm 2.1$ & $231.4 \pm 28.8$ & $0.8 \pm 0.04$ & $9.4 \pm 0.9$ \\
\hline
\end{tabular}


Table 5. Mycorrhizal frequency of pine growing in experimental areas.

\begin{tabular}{|c|c|c|c|}
\hline Spot & Piekary Śl. /heap/ & Miasteczko Śl. & Kokotek \\
\hline Total mycorrhizas & ++++ & ++++ & ++ \\
\hline Including revived viable mycorrhizas & +++ & +++ & ++++ \\
\hline
\end{tabular}

+ very little; ++ little; +++ high; ++++ very high

Table 6. Contents of cadmium and lead in seedlings from pot experiments ( $\mu \mathrm{g} / \mathrm{g}$ dry mass); mean $\pm \mathrm{SD}$.

\begin{tabular}{|c|c|c|c|}
\hline \multicolumn{3}{|c|}{ Mycorrhizal } & Non-mycorrhizal \\
\hline $\mathrm{Cd}$ & $\mathrm{Pb}$ & $\mathrm{Cd}$ & $\mathrm{Pb}$ \\
\hline \multicolumn{4}{|c|}{ Roots } \\
\hline $29.0 \pm 2.7$ & $254.3 \pm 6.8$ & $17.9 \pm 1.2$ & $219.5 \pm 3.8$ \\
\hline \multicolumn{4}{|c|}{ Aboveground part of seedlings } \\
\hline $2.2 \pm 0.3$ & $24.3 \pm 1.4$ & $16.6 \pm 1.3$ & $189.7 \pm 3.6$ \\
\hline
\end{tabular}

The protective role of mycorrhizae was observed in control tests (performed in the frame of this work), which is in agreement with other researchers. Table 6 shows a difference in accumulation of tested metals depending on whether the pine seedlings were mycorrhizal or free from fungi. In mycorrhizal pine seedlings, metals were deposited mainly in the underground parts (in mycorrhiza). The aerial part mainly was protected against excessive contamination by cadmium and lead. This dependence was not observed in the case of non-mycorrhizal seedlings. The effectiveness of the mycorrhizal pine seedlings protection may be the fact that non-mycorrhizal plants treated with solutions of heavy metals died after 2-3 months of cultivation, while mycorrhizal plants grown under identical conditions were still alive and their vegetation could last for about a year.

All these observations suggest that the ectomycorrhizal fungus could affect the sorption and the movement of mineral salts and heavy metals.

In light of our results, it appears that increments of plant resistance to contamination are due mainly not so much to the limitations of heavy metal ion collection but to its filtering by mycorrhizae $[37,38]$.

In order to investigate how higher plants can tolerate lead pollution in the environment, other groups checked the development of mycorrhized pine seedlings grown in the presence of lead. Bizo et al., observed that $\mathrm{Pb}$ uptake was prominent in the roots, while a smaller amount was found in pine needles [39].

Mycorrhizal fungi form mutualistic associations with the roots of $80-90 \%$ of vascular plant species and may constitute up to $50 \%$ of the total soil microbial biomass. Arbuscular mycorrhizal fungi have been considered to enhance phytoremediation of hydrocarbon-contaminated sites [8].

Comparative analysis of microscopic, macroscopic and molecular of isolate of the mycelium M1 allowed

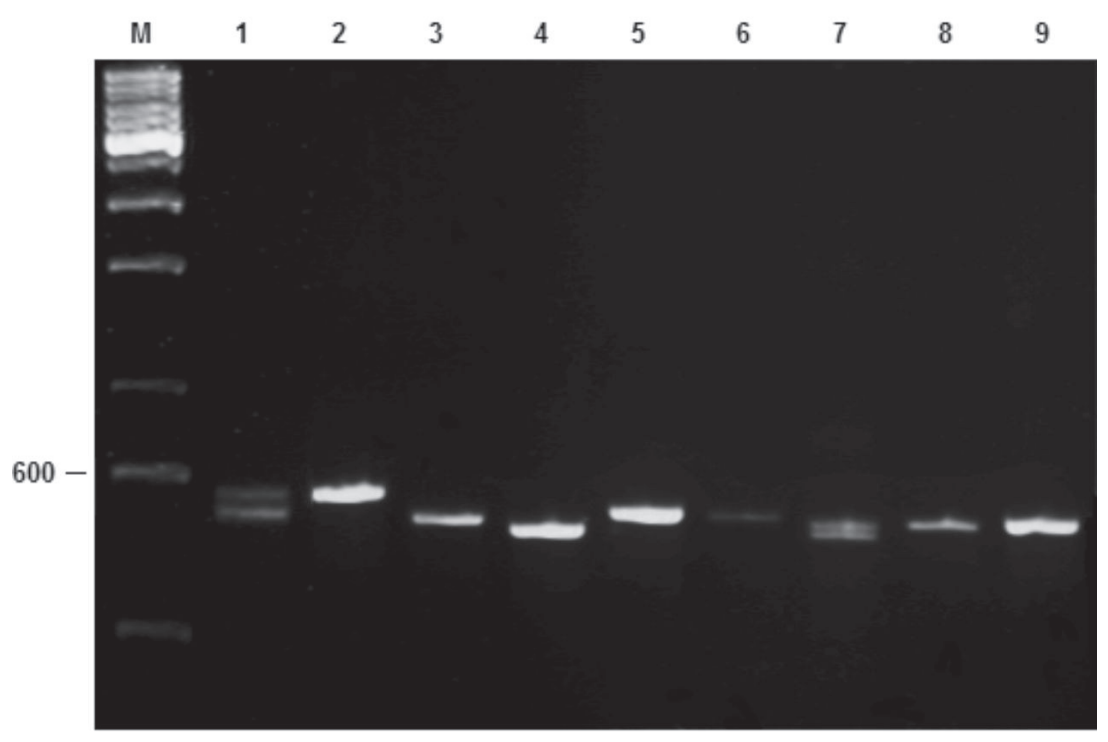

Fig.1. Gel electrophoresis showing RFLP patterns of PCR-amplified 18S-28S rDNA ITS regions from various types of fungi; Lane M, 100-bp DNA size marker; Lane 1 - Amanita citrina; Lane 2 - Amanita muscaria; Lane3 - Xerocomus badius; Lane 4 - Boletus edulis, Lane 5 -Suillus luteus, Lane 6 - Paxillus involutus, Lane 7 - Cantharellus cibarius, Lane 8 - Tricholoma equestre, Lane9-Rubroboletus satanas. 


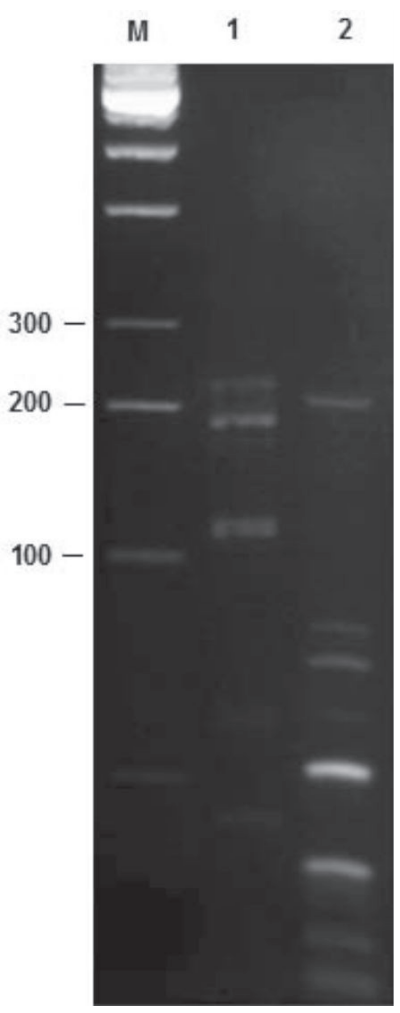

Fig. 2. Gel electrophoresis showing RFLP patterns of PCRamplified 18S-28S rDNA ITS regions from A. muscaria Lane M, 100-bp DNA size marker; Lane 1, digestion with AluI; Lane 2, digestion with $T a q \mathrm{I}$.

for the hypothesis that leading fungus isolated from the roots of pine (which then was used for artificial mycorrhiza of seedlings) was toadstool Amanita muscaria (Figs 1-2). This hypothesis is also confirmed by the mass appearance of fruiting bodies of this species on the experimental plot in Miasteczko Ślaskie, where mycorrhizae were collected in order to derive the experimental line of M1 strain.

\section{Conclusions}

1. Ectomycorrhizal fungi coexisting with the roots of pines actively stop the flow of heavy metals, thus facilitating the growth and development of the tested plants in areas degraded by industry.

2. The accumulation of heavy metals in the pine organs by the action of mycorrhiza is not proportional to their concentration in the soil.

3. The amount of heavy metals leachable by water from the soil is not proportional to the total content of these metals.

4. In areas with high heavy metals contamination of soils we observed an increase in mycorrhizal infection and the formation of ectomycorrhizas characterized by a short life.

5. Mycological observations and mycorrhizal research in plant communities on contaminated soils with heavy metals highlights the presence of mushroom Amanita muscaria as a pine tree mycorrhizal symbiont.

\section{Conflict of Interest}

The authors declare no conflict of interest.

\section{References}

1. LEEA S-H., KIMB E-Y., HYUNC S., KIMC J-G. Metal vailability in heavy metal-contaminated open burning and open detonation soil: Assessment using soil enzymes, earthworms, and chemical extractions. J. Hazard. Mat. 170, 382, 2009.

2. PATEL A., PATRA D.D. Influence of heavy metal rich tannery sludge on soil enzymes vis-à-vis growth of Tagetes minuta, an essential oil bearing crop. Chemosph. 112, 323, 2014.

3. LEMANOWICZ J., BARTKOWIAK A. Content of selected macronutrients and heavy metals and the activity of phosphomonoesterases in soil affected by illegal dumping sites. Arch. Gosp. Odp. Ochr. Środow. 17 (3), 19, 2015.

4. WEN Z., SHI L, TANG Y, SHEN Z, XIA Y, CHEN $Y$. Effects of Pisolithus tinctorius and Cenococcum geophilum inoculation on pine in copper-contaminated soil to enhance phytoremediation. Int. J. Phytoremediation. 19 (4), 387, 2017.

5. KRZNARIC E., WEVERS J.H., CLOQUET C., VANGRONSVELD J., VANHAECKE F., COLPAERT J.V. $\mathrm{Zn}$ pollution counteracts $\mathrm{Cd}$ toxicity in metaltolerant ectomycorrhizal fungi and their host plant, Pinus sylvestris. Environ. Microbiol. 12 (8), 2133, 2010.

6. HUANG X., WANG L., ZHU S., HO SH., WU J., KALITA PK., MA F. Unraveling the effects of arbuscular mycorrhizal fungus on uptake, translocation, and distribution of cadmium in Phragmites australis (Cav.) Trin. ex Steud. Ecotoxicol. Environ. Saf. 149, 43, 2018.

7. HUANG X, WANG L, MA F. Arbuscular mycorrhizal fungus modulates the phytotoxicity of $\mathrm{Cd}$ via combined responses of enzymes, thiolic compounds, and essential elements in the roots of Phragmites australis. Chemosphere. 187, 221, 2017.

8. RAJTOR M., PIOTROWSKA-SEGET Z. Prospects for arbuscular mycorrhizal fungi (AMF) to assist in phytoremediation of soil hydrocarbon contaminants. Chemosphere 162, 105, 2016.

9. RINEAU F., ROSE CH., LE THIEC D., GARBAYEL J. Liming in a beech forest results in more mineral elements stored in the mantle of Lactarius subdulcis ectomycorrhizas. Fung. Biol. 114, 1007, 2010.

10. BECHEM E.E.T., ALEXANDER I.J. Phosphorus nutrition of ectomycorrhizal Gnetum africanum plantlets from Cameroon. Plant. Soil 353, 379, 2012.

11. HAY T.N., PHILLIPS L., NICHOLSON B.A., JONES M.D. Ectomycorrhizal community structure and function in interior spruce forests of British Columbia under long term fertilization. Forest Ecol. Managem. 350, 87, 2015.

12. NAMIEŚNIK J., ŁUKASIAK J., JAMRÓGIEWICZ Z. Pobieranie próbek środowiskowych do analizy, eng. Taking samples for analysis. Pod red. J. Namieśnika. Warszawa: Wydaw. Naukowe PWN, 1995. 
13. WYCIŚLIK A. Pobieranie próbek środowiskowych do badań składu chemicznego - praktyczne wskazówki i źródła błędów, eng. Environmental sampling for chemical composition tests - practical tips and sources of errors. Środ. Roz. 17 (1), 2008.

14. KRUPA P. Ektomikoryzy i ich znaczenie dla drzew rosnących na terenach zanieczyszczonych metalami ciężkimi, eng. Ectomycorrhizae and their importance for trees growing in areas contaminated with heavy metals. Wydawnictwo Uniwersytetu Śląskiego. Katowice 2004.

15. RESZKE E. Mineralizacja mikrofalowa, eng. Microwave mineralization. Analityka: nauka i praktyka. 4, 22, 2001.

16. MAŁYSZKO J. Metody miareczkowania kulometrycznego, eng. Coulometric titration methods. Wiad. Chem. 65, 5, 2011.

17. KRUPA P., KOZDRÓJ J. Ectomycorrhizal fungi and associated bacteria provide protection against heavy metals in inoculated pine (Pinus sylvestris L.) seedlings. Water Air Soil. Pollut. 182 (1), 83, 2007.

18. CABALA J., ZOGALA B., DUBIEL R. Geochemical and geophysical study of historical $\mathrm{Zn}-\mathrm{Pb}$ ore processing waste dump areas (Southern Poland). Pol. J. Env. Stu. 17 (5), 693, 2008.

19. FIJAŁKOWSKI K., KACPRZAK M., GROBELAK A., PLACEK A. The influence of selected soil parameters on the mobility of heavy metals in soils. Eng. Prot. Environ. 5, 81, 2012.

20. JUNG S.C., MARTINEZ-MEDINA A., LOPEZ-RAEZ J.A., POZO M.J. Mycorrhiza-induced resistance and priming of plant defenses. J. Chem. Ecol. 38 (6), 651, 2012.

21. HODGSON E. A Textbook of Modern Toxicology 4. John Wiley \& Sons, New Jersey. 2010.

22. BARAN A., WIECZOREK J. Ocena zagrożenia związanego z zawartością metali ciężkich w glebach na terenie powiatu olkuskiego (woj. małopolskie). eng. Risk assessment related to the content of heavy metals in soils in the powiat olkuski (woj. małopolskie). Proc. EcOpole. 7 (1), 281, 2013.

23. CZECH T., BARAN A., WIECZOREK J. Zawartość metali ciężkich $\mathrm{w}$ glebach $\mathrm{i}$ roślinach $\mathrm{z}$ terenu gminy Borzęcin (województwo małopolskie). eng. The content of heavy metals in soils and plants from the commune of gmina Borzęcin (województwo małopolskie). Inż. Ekol. 37, 89, 2014.

24. Rozporządzenie Ministra Środowiska z dnia 9 września 2002 r. w sprawie standardów jakości gleby oraz standardów jakości ziemi. Dz. U. 2002, No. 165, item. 1359. eng. Regulation of the Minister of the Environment of 9 September 2002 on soil quality standards and earth quality standards. Dz. U. 2002, No. 165, item. 1359.

25. KLAASSEN C. Casarett \& Doull's Toxicology: The Basic Science of Poisons. McGraw-Hill Professional, New York. 2007.

26. GAO Y.-CH., GUO S.-H., WANG J.-N., LI D., WANG H., ZENG D.-H. Effects of different remediation treatments on crude oil contaminated saline soil. Chemosphere 117, 486, 2014.

27. PHIELER R., MERTEN D., ROTH M., BÜCHEL G., KOTHE E. Phytoremediation using microbially mediated metal accumulation in Sorghum bicolor. Env. Sci. Poll. Res. 2015.22/ 24: 19408-19416, 2015.

28. SZUBA A. Ectomycorrhiza of Populus. Forest Ecol. Manag. 347, 156, 2015.

29. MOHAN J. E., COWDEN Ch. C., BAAS P., DAWADI A., FRANKSON P. T., HELMICK K., HUGHES E., KHAN S., LANG A., MACHMULLER M., TAYLOR M., WITT C. A. Mycorrhizal fungi mediation of terrestrial ecosystem responses to global change: mini-review. Fung. Ecol. 10, 3, 2014.

30. SOUSA N.R., FRANCO A.R., OLIVEIRA R.S., CASTRO P.M.L. Ectomycorrhizal fungi as an alternative to the use of chemical fertilisers in nursery production of Pinus pinaster. J. Environ. Manag. 95, S269-S274, 2012

31. LE TACON F., ZELLER B., PLAIN C., HOSSANN Ch., BRÉCHET C., MARTIN F., KOHLER A., VILLERD J., ROBIN Ch. Study of nitrogen and carbon transfer from soil organic matter to Tuber melanosporum mycorrhizas and ascocarps using $15 \mathrm{~N}$ and $13 \mathrm{C}$ soil labelling and wholegenome oligoarrays. Plant Soil. 395 (1-2), 351, 2015.

32. JOURAND P., HANNIBAL L., MAJOREL C., MENGANT S., DUCOUSSO M., LEBRUN M. Ectomycorrhizal Pisolithus albus inoculation of Acacia spirorbis and Eucalyptus globulus grown in ultramafic topsoil enhances plant growth and mineral nutrition while limits metal uptake. J. Plant Physiol. 171 (2), 164, 2014.

33. KARLIŃSKI L., RUDAWSKA M., LESKI T. The influence of host genotype and soil conditions on ectomycorrhizal community of poplar clones. Eur. J. Soil Biol. 58, 51, 2013.

34. BOJARCZUK K., KIELISZEWSKA-ROKICKA B. Effect of ectomycorrhiza on $\mathrm{Cu}$ and $\mathrm{Pb}$ accumulation in leaves and roots of silver birch (Betula pendula Roth.) seedlings grown in metal-contaminated soil. Water Air Soil Poll. 207 (1-4), 227, 2010.

35. LUO Z.-B., WU Ch., ZHANG Ch., LI H., LIPKA U., POLLE A. The role of ectomycorrhizas in heavy metal stress tolerance of host plants. Envir. Exp. Bot. 108, 47, 2014.

36. SCHLUNK I., KRAUSE K., WIRTH S., KOTHE E. A transporter for abiotic stress and plant metabolite resistance in the ectomycorrhizal fungus Tricholoma vaccinum. Envir. Sci. Poll. Res. 22, 19384, 2015.

37. ŠIRIĆ I., KASAP A., BEDEKOVIĆ D., FALANDYSZ J. Lead, cadmium and mercury contents and bioaccumulation potential of wild edible saprophytic and ectomycorrhizal mushrooms, Croatia. J. Environ. Sci. Health. B. 54 (3), 156, 2017.

38. ŠIRIĆ I., HUMAR M., KASAP A., KOS I., MIOČ B., POHLEVEN F. Heavy metal bioaccumulation by wild edible saprophytic and ectomycorrhizal mushrooms. Environ. Sci. Poll. Res. Int. 23 (18), 18239, 2016.

39. BIZO M.L., NIETZSCHE S., MANSFELD U., LANGENHORST F., MAJZLAN J., GÖTTLICHER J., OZUNU A., FORMANN S., KRAUSE K., KOTHE E. Response to lead pollution: mycorrhizal Pinus sylvestris forms the biomineral pyromorphite in roots and needles. Environ. Sci. Pollut. Res. Int. 24 (16), 14455, 2017. 
